\title{
How to get off the MX hook
}

\section{The US Congress has slapped the Administration in the face by denying funds for MX construction: the problem now, for all concerned, is to find a more manageable missile defence.}

The Reagan Administration's defeat in Congress on the MX missile is humiliating but well deserved. Since President Carter's time, it has been understood between the executive and the legislative branches of the United States government that this expensive weapon would not be built until some way had been found of deploying it so as to give both generals and taxpayers some assurance that a substantial proportion of the missiles would survive a first attack from somewhere else. President Carter's favourite solution, shuttling missiles about a dedicated subway system, could have been effective if his Congress had not jibbed at the cost. President Reagan's high-tech solution of the same problem - putting missiles so close together that one attack will neutralize the next - is much more ingenious but even less credible (see Nature 2 December, p.389). People skilled at the assessment of the damage done by nuclear weapons say that they understand why "dense pack" should be safe, but acknowledge (as if it were a minor oversight) that they should have given other people more time to understand. What the US Congress has now asked is that if, with the benefit of all the briefings to which it has been privileged in the past few weeks, it cannot understand how dense-packed MX could survive, what reason is there to suppose that a hostile power (any hostile power) would be so persuaded of the inviolability of some part of an MX force that it would refrain from a first strike?

The same point bears even more directly on what congressmen's (or women's) constituents think about MX. If a missile-park in Wyoming should fall short of seeming to a potential enemy a viable retaliatory force, why should it seem a good investment of tax dollars to the electors in congressional districts? Congressmen (and women) have learned in the past few years, often against their predispositions, that nothing is as certain to crowd out a community hall, or a town square, than an invitation to protest against MX, or nuclear arms as such or, even, against nuclear things (such as nuclear reactors) in an even broader sense. Latterly, the federal government has been brought face to face with this sombre truth by the knowledge that there is a standing army of a quarter of a million people ready to fill the space around the Washington Monument whenever the call goes out for a protest against something nuclear.

So, in their small ways, congressmen (and women) are already individually paying a price for the $\mathrm{MX}$ and what is called its "basing mode". The chances are that even the federal government, a loose synonym for the Reagan Administration, will not be able to survive indefinite rebellion against an unconvincing case for nuclear reinforcement. The danger now is that if the Administration insists that its scheme for the deployment of MX is, for all its faults, the best that it can think of, it will merely widen the gulf between itself and those among its taxpayers who dissent. The Administration has to learn to live with its nuclear opposition.

The military have an important part to play in helping to square this essentially political circle. Many of those who disbelieve in Dense Pack do so because they know in their bones that the technical attributes of the MX missile are an impediment to more sophisticated means of deployment. The ideal, of course, would be that missiles such as MX should be made stochastically invulnerable to destruction from some other missile force by their mobility, and by the opportunities for deception that mobility provides. Putting missiles such as MX in ocean-going submarines may serve well enough for a counter-city force, but the accuracy is not great enough for a missile force intended to knock out other missiles. The simple resolution of this military dilemma, of course, is to acknowledge that MX (which will weigh at least 100 tonnes) is too big to be mobile, and that it would therefore be better to start from somewhere else - say an upgraded version of the submarine-launched Trident, the land-based version of which is known as D-4. Better still, why not go for a much smaller missile that need not weigh more than 10 tonnes or so - mobile enough to be carried on almost any kind of vehicle?

Politically, the US Administration cannot openly embrace such a solution. To embark all over again on the construction of another strategic weapons system would seem like vacillation to the voters and like weakness to potential enemies. Technically, however, there are viable solutions. It would be possible, for example, to build some extra submarines equipped with missiles so as temporarily to keep potential aggressors in their places. That arguments of this kind may have persuaded the Soviet Union, in the mid-1960s, to plan enormously to increase its deployment of strategic missiles is probably, in retrospect, irrelevant. What matters now is merely that the arms race has a curiously irreversible character. If one side builds a new strategic weapons system, the other is likely to follow suit and the result is likely to be a permanent increase of mutual striking power. Building a system like MX is hard enough, but dismantling it is even harder.

Hitherto, the fruits of negotiations on the limitation of strategic arms, such as those that have been taking place at Geneva for almost a year, have been negligible in comparison with what the arms manufacturers have accomplished. Technically, however, there is a way out even from that conundrum: settle for the ratifications of a few simple arms control agreements already negotiated, the threshold test-ban treaty, the agreement to prohibit except under tight controls peaceful nuclear explosions and even Salt II.

The moral, in short, is that if Congress will not give the Administration what it wants, a deterrent that is the opposite of credible in the sense that those who have paid for it do not believe in it, and if (which is not necessarily the case) it is impossible to start again, the Reagan Administration will have to acknowledge that there is no serious alternative to serious negotiations on arms control. As it happens, the Administration has been presented, in the Geneva negotiations on the limitation of intermediate-range weapons in Europe, with an awkward problem on which to brood over the Christmas vacation; the Soviet Union has offered to reduce the number of nuclear warheads based on SS-20 missiles to 300 if only the United States will refrain from putting Pershing II and cruise missiles on their allotted bases in Europe by the end of 1983, and also agree (which is impossible) that the United Kingdom and France should fall in with whatever the superpowers eventually decide. The terms offered are unacceptable not simply because they are unattainable but because they would also be inequitable; they are nevertheless the best prospect at Geneva for a year. The United States should recognize the offer as an opportunity to throw the theatre and strategic weapons negotiations together (where they belong), for winning some arms control agreement below present levels and for escaping from the MX hook. 